るベーシックな汎用性のあるシステムの開発はできない ものかと思った.

演題289はバリアン社の新製品の報告である.近未来を 見すえた機能が特徴である.セールスポイントの機能に ダイナミック治療がある. ダイナミック治療なるものが これから多用されるのか，されるとすると照射法も多様 化されるであろう、ポータルビジョン（リヤルタイムイ メージングシステム) もオプションであるが開発されて いる.これらも単にポータルフィルムの代替で終わるの か, 放射線治療の画像利用に大きく貢献するのか未知数 である.とにかく現時点に扔いて究極の治療機の一つで あることは間違いなく, 新しい照射法の将来を暗示して いると感じた。

演題290は愛知県がんセンターで開発された放射線治 療総合システムの最後に残った画像端末開発の報告であ る. 問題点として画像転送速度を述べているが，ハード の問題であり将来的には解決されるであろう．放射線治 療に括ける画像の利用はこれからも多くなると予想され るが，画像利用方法と使用頻度が問題となる，画像利用 方法は経験を積まなければならないし，それによって画 面構成もおのずと決まってくる. 使用頻度は治療計画時 と治療期間中の利用が主で治療終了後の利用がどのくら いあるのか知りたい所である。それに演者も述べている 办画像入力を誰が行うかの問題もあり，PACSが採用さ れれば治療部門は画像を利用するだけなので一番恩恵に 浴することになる。

演題291はX線シミュレータの画像をパソコンに取り 迟んで照射野やブロックの位置を決定しようとするもの である.ブロックの位置採取は苦労する所であるが OHP シートにプリントアウトすることで省力化できる. これと類似の方法にRTマーカシステム（国立がんセン ター; 神戸大)がある.しかし， CT を治療に使用できな い施設では有用な方法である。器具もパソコンとプロッ タだけであり，多くの施設で利用できるシステムである。 欲を言えば液晶のディスプレイが発売されているので, シミュレータと治療機に取り付ければ OHP シートを用 いないで，より有用なシステムとなる。

演題 292 は実用的に難があるが興味ある報告である.撮 像時間，画像再構成時間もまずまずであるが, 空間分解 能が悪いのは高エネルギーX線を使う宿命か？ 演者が 述べている“患者体内の線減弱係数分布が直接得られる” のであれば線量分布計算の精度向上が望める. スカウ卜 ビュウは撮れるのか，また治療計画にはそれを利用した らどうか(大阪成人セ,川辺)，この研究にどのくらい費
用が必要か（伊勢総合病院，羽柴）という質問が出た。 スカウトビュウは考えていない, 費内は不明とのことで あった. 基礎的な研究であり，ディテクターの改良開発 あるいは画像処理方法が今後の問題であろう。研究を継 続されてステップアップした報告を期待したい。

\section{治療-8 不均質補正（演題番号293～295）}

\section{加藤秀起（愛知医科大学附属病院）}

本セッションでは, 放射線治療技術における重要な研 究テーマのひとつである不均質補正に関しての研究が 3 題報告された.

演題293（筑波大田村）は，JASTRO 不均質臨床ファ ントムを用い，JARP 型線量計での実測が困難な均質・ 不均質部の境界近傍や照射野辺縁部の線量分布測定を， フィルム法により行った場合の精度などについての研究 報告である．JAPP 型線量計による測定值と比較すると， 精度, 再現性に問題が残るが; フィルムの持つ優れた空 間分解能により，線量が急激に変化する領域での 2 次元, 3 次元的線量分布評価に有効であると報告した。

質問 座長 もっとも基本となる水等価均質モデルの ほうが，不均質モデルよりも，JAPP 型線量計による PDD に対する平均誤差が大きくなるのはなぜか.

答 森 共同演者 これはフィルムのエネルギーレス 水ンスに起因するもので，不均質モデルに比べて水等価 均質モデルのほうがファントム内で散乱線寄与率の変化 が大きく, その結果, 測定点によりフィルムのエネルギ ーレスポンスの変化が大きくなるためである.

演題294 (国立熊本病院荒木).は，JASTRO 不均質標 準ファントム（胸部モデル）を用い, 胸壁厚の違いによ る肺補正係数の変動, およびRTAR, PTAR, ETAR の 3 方法にようて計算される補正係数の精度について調べ た研究報告である!肺内に扔いて電子平衡が成立する深 さ以上では補正係数は壁厚に依存せずに一致する，また， 小照射野では PTAR 法が一番精度が良く，照射野が大 きくなるとETAR 法が最も精度が良くなるとの報告で あった。

質問，森（鈴鹿医科技大）（1)演者の施設では10 MV $\mathrm{X}$ 線で肺癌を照射しているのか. (2)実際にはどの補正法 で計算しているのか.

答 荒木 (1) $10 \mathrm{MV} \mathrm{X}$ 線で照射している.コバルト装 置もあるが半影を考慮して肺癌照射には使用していない. (2)線量分布作成のみ RTAR で補正計算しているが, モ ニターユニットの計算には補正を行っていない.

意見 森（鈴鹿医科技大） $10 \mathrm{MV} \mathrm{X}$ 線小射野では, 
どの補正法で計算しても大きな誤差が生じる。極端に言 えば，補正をしないほうが精度が良い場合もある，治癒 可能な肺癌に対しては, 線量評価が困難な $10 \mathrm{MV}$ X線は 適していないと考える。

演題295（天野医院丸石）は，微分散乱法の考え方を 2 次電子によるエネルギー伝播に応用した高エネルギーX 線に対する不均質補正，特に 1 次線線量評価法に関する 演者らの一連の研究の一つであり, 今回は, 不均質部の 境界近傍での，電子の多重散乱に起因する計算誤差を補 正する方法に関する研究報告である．2 次電子飛程の途 中で密度が変化することによる行跡角度の変化傾向に着 目し，これを電子発生点・計算点間の距離およびその平 均密度などの関数で数式化することにより，多重散乱に 起因する計算誤差をある程度補正することができると報 告した.

質問：渡辺 (北海道大). 電子飛程の途中に密度の変化 があった場合，実際的に微分散乱量の 3 次元デー夕をど のように変化させるのか.

答 丸石 CT データなどの 3 次元密度分布テーブル を利用して，2 次電子発生点と計算点とを結ぶ值線上の 平均密度を計算し，それを Scaling して刘応する微分散 乱值を使用する。

意見 森（鈴鹿医科技大） ここの微分散乱法をさらに 発展させて, 今後本当の意味で臨床に役に立つ研究にし て行ってもらいたい。

放射線治療において $5 \%$ 以内の誤差で線量を投与する ためには，精度の良い不均質補正法の開発が不可欠であ る、不均質補正アルゴリズムについては，これまでに多 数の研究報告がなされているが，現時点において，あら ゆる照射条件で精度が良く，かつルチンの治療計画で利 用できる補正方法はないのが現状である。本セッション の研究発表を通して, 実際の放射線治療計画コンピュー 夕に登載可能な 2 次電子飛程を考慮した不均質補正アル ヨ゙リズムの杲期開発の必要性が強く感じられた。

\section{単純撮影- 3 乳房（演題番号296～301）}

千安式部（神奈川県立足柄上病院）

当演題群は, 乳房撮影に関する計 6 題の展示発表であ る。 演題296, 演題297の 2 演題は, 東海 3 県および近畿 1 府3 県の地域におりる乳房撮影の筷態を調查し, 分析 結果より問題点を示したものである。堀田，寺田らはと もに，調查項目全てに問題があり，技術的対応が不適切 であることを指摘している。早急に技術的標準化，精度 管理などの推進と啓蒙を強く求めている. 本学会のみな
らず，関連学会とも共同し，これらを具体化することに 座長も賛同した。

演題298は, 乳房スポット像には高 $\gamma$ フィルムが有効 であることは報告済みである。今回はフィルム 3 種, 増 感紙 6 種（相対感度100～220）計18種類の組み合わせに より，スクリーニング像，スポット像に有効な増感紙の 選択のため，ファントムおよび手術標本を用いて撮影し， 放射線医・外科医の視覚的評価を通して検討している. これによると，スポット像では低感度・高鮮鋭度増感紙 が評価値が高く, 中・高感度増感紙は, スクリーニング 像：スポット像とも評価が変わらない傾向を示したと結 論している．会場の逸見氏（倉敷成人病）らは，実験， 評価方法などを工夫すれば，もう少し明確な結論が得ら れたのではないかという旨の意見もあった。演題299は， 腫瘤を触知せずマンモグラフィ上で微少石灰化を認め, 生検前マーキングを行い，病理確定診断のついた49症例 について, 石灰化の大きさ, 形状, 分布などから良・悪 性の判定基準を求めようという研究である.今回は, 症 例数も少なくマンモグラフィ上の石灰化像のみからの 良・悪性の判定は困難であり，明らかな良性石灰化以外 は,フックワイヤなどによるバイオプシィが必須である と結論付けしている.

演題300は, $0.2 \sim 0.4 \mathrm{~mm} \phi\left(\mathrm{ca}(\mathrm{OH})_{2}\right)$ ) 7 種類の微 小石灰化モデルを配した自作フアントムを用い，S/F 系 と CRによる視覚的検出能を密着および 2 倍拡大撮影に ついて比較検討を行っている。密着撮影は， S/F 系, CR ともほほ同等あるが，フアントム厚が増すと CR のほう がやや劣化程度が小さい傾向がある。 また 2 倍拡大では， CRが有意に優れていると結論ゔけている.

演題301は, マンモグラフィの粒状性の良否は乳がんの 重要な所見である微小石灰化の描出能に密接に関係する ことを指適し, CR マンモグラフィにおける粒状性を, お のおの, 出力階調, L值, 線量の変化とオーバーオール ウィナスペクトルとの関連で評価している。このことか ら，階調挍よび線量との関連性を明らかにしている。 CR マンモグラフィの粒状性の管理は, 適切な線量 (IP 入射 線量）と，それに相応した階調の選択が重要であること を述べている.

バリウム造影剤（演題番号302～306）

岡田 健（小諸厚生総合病院）

本セッションは, 上部・下部消化管 4 題である。その 内容と傾向は，本年 4 月より施行された第 3 次老健保健 事業に沿った内容であったことは大変嬉しいことである。 